\title{
Long-term administration of fenspiride has no negative impact on bone mineral density and bone turnover in young growing rats
}

\author{
Agnieszka Matuszewska ${ }^{1, A-F}$, Beata Nowak1,A-F, Diana Jędrzejuk 2,B,C, Marcin Landwójtowicz ${ }^{2, B, C}$, Marek Bolanowski2, ${ }^{2, E}$, \\ Wojciech Dziewiszek ${ }^{1, B}$, Anna Merwid-Ląd $d^{1, D, E}$, Ewa Szeląg ${ }^{3, B, C}$, Krzysztof Zduniak ${ }^{4, B, C}$, Joanna Kwiatkowska ${ }^{1, B, C}$, Adam Szeląg , $^{1, A, E, F}$ \\ ${ }^{1}$ Department of Pharmacology, Wroclaw Medical University, Poland \\ ${ }^{2}$ Department of Endocrinology, Diabetology and Isotope Therapy, Wroclaw Medical University, Poland \\ ${ }^{3}$ Department of Maxillofacial Orthopedics and Orthodontics, Wroclaw Medical University, Poland \\ ${ }^{4}$ Department of Pathomorphology, Wroclaw Medical University, Poland \\ A - research concept and design; B - collection and/or assembly of data; C - data analysis and interpretation; \\ $D$ - writing the article; $E$ - critical revision of the article; $F$ - final approval of the article
}

Address for correspondence

Beata Nowak

E-mail: beata.nowak@umed.wroc.pl

Funding sources

The research was supported with a Wroclaw Medical University Grant for Young Researchers (Pbmn 138).

Conflict of interest

None declared

Received on March 1, 2018

Reviewed on June 5, 2018

Accepted on July 24, 2018

Published online on March 6, 2019

Cite as

Matuszewska A, Nowak B, Jędrzejuk D, et al. Long-term administration of fenspiride has no negative impact on bone mineral density and bone turnover in young growing rats. Adv Clin Exp Med. 2019;28(6)::771-776. doi:10.17219/ acem/93729

DOI

10.17219/acem/93729

Copyright

Copyright by Author(s)

This is an article distributed under the terms of the

Creative Commons Attribution Non-Commercial License

(http://creativecommons.org/licenses/by-nc-nd/4.0/)

\begin{abstract}
Background. Fenspiride is an antagonist of H1-histamine receptors that is used to treat acute and chronic respiratory tract infections and otitis media in children and adolescents

Objectives. The aim of the study was to assess the influence of long-term administration of fenspiride on bone mineral density (BMD) and bone turnover in young growing rats.

Material and methods. The experiment was carried out on 18 young (8-week-old) male Wistar rats receiving either fenspiride $15 \mathrm{mg} / \mathrm{kg}$ intragastrically (ig) (group F) or saline solution $4 \mathrm{~mL} / \mathrm{kg}$ ig (group C) for 3 months. On days 1 and 93, blood samples were collected and serum levels of calcium, phosphorus and markers of bone turnover were measured. On days 2 and 92, BMD was measured with dual-energy X-ray absorptiometry (DXA) using small animal software.

Results. We detected no influence of fenspiride on weight gain, total body BMD $\left(0.212 \pm 0.010 \mathrm{~g} / \mathrm{cm}^{2}\right.$ vs $\left.0.204 \pm 0.024 \mathrm{~g} / \mathrm{cm}^{2}\right)$, hind limb BMD $\left(0.264 \pm 0.016 \mathrm{~g} / \mathrm{cm}^{2}\right.$ vs $\left.0.252 \pm 0.027 \mathrm{~g} / \mathrm{cm}^{2}\right)$, or bone macroscopic parameters. There were no significant differences between group $\mathrm{F}$ and group C in serum levels of osteocalcin (group F: $0.42 \pm 0.09 \mathrm{ng} / \mathrm{mL}$ vs group C: $0.43 \pm 0.08 \mathrm{ng} / \mathrm{mL}$ ), C-terminal telopeptide of type I collagen (F:0.31 $\pm 0.08 \mathrm{ng} / \mathrm{mL}$ vs C: $0.29 \pm 0.08 \mathrm{ng} / \mathrm{mL}$ ), osteoprotegerin (F: $5.47 \pm 0.78 \mathrm{pg} / \mathrm{mL}$ vs $C: 5.35 \pm 1.65 \mathrm{pg} / \mathrm{mL}$ ), receptor activator of nuclear factor kappa B ligand (F:0.65 $\pm 0.85 \mathrm{pg} / \mathrm{mL}$ vs $C: 0.56 \pm 0.86 \mathrm{pg} / \mathrm{mL}$ ), parathormone (F: $237 \pm 182 \mathrm{pg} / \mathrm{mL}$ vs C: $289 \pm 200 \mathrm{pg} / \mathrm{mL}$ ), total calcium (F: $6.38 \pm 1.50 \mathrm{mg} / \mathrm{dL}$ vs C: $6.83 \pm 1.71 \mathrm{mg} / \mathrm{dL}$ ), or inorganic phosphorus (F: $5.19 \pm 1.76 \mathrm{mg} / \mathrm{dL}$ vs $(: 5.50 \pm 1.32 \mathrm{mg} / \mathrm{dL}$ ).
\end{abstract}

Conclusions. Long-term administration of fenspiride has no negative impact on BMD and bone metabolism in young growing rats.

Key words: rats, histamine, bone mineral density, bone, fenspiride 
Osteoporosis is a generalized bone disease characterized by low bone mass and disorders of bone architecture leading to increased susceptibility and, in consequence, to fractures. ${ }^{1}$ Osteoporosis and osteoporotic fractures generate high costs of medical care, physical disability and increased mortality. In 2010, it was estimated that in Europe osteoporosis affects 22 million women and 5.5 million men, with 3.5 million new bone fractures per year, including 610,000 hip fractures, 520,000 vertebral fractures, 560,000 forearm fractures, and 1.8 million fractures in other localizations. ${ }^{2}$

Achieving the proper peak bone mass (PBM) in young people (25-30 years) is extremely important for decreasing the risk of osteoporosis and fractures in adulthood ${ }^{3}$ and possibly in the elderly. ${ }^{4}$ In young organisms, intensive bone turnover is observed, with bone formation predominant over bone resorption. As a result, the skeleton achieves the appropriate size, shape, and weight of bones. ${ }^{5}$ The maximum PBM value depends on many different variables, such as genetic, hormonal and environmental factors. ${ }^{4}$ Many drugs may have significant impact on bone mineral density (BMD) and bone metabolism in children (glucocorticoids, methotrexate, antiepileptic drugs). ${ }^{6,7}$ Therefore, it is important to assess the influence of various drugs on growing bones.

Fenspiride is used to treat acute and chronic respiratory tract infections and otitis media in children and adolescents. It is an H1-antihistamine agent that decreases the synthesis of pro-inflammatory mediators (cytokines, tumor necrosis factor $\alpha$ (TNF- $\alpha$ ), prostaglandins, leukotrienes, and free radicals) and relaxes the smooth muscles, similarly to papaverine. ${ }^{8-10}$ The presence of $\mathrm{H} 1$-histamine receptors on both osteoblasts and osteoclasts has been confirmed. ${ }^{11}$ Pro-inflammatory cytokines, e.g., interleukin-1, interleukin- 6 and TNF- $\alpha$, increase osteoclast activity through the RANK/RANKL/OPG pathway and inhibit osteoblast activity. Prostaglandins may stimulate both bone formation and bone resorption. ${ }^{12}$ Leukotrienes inhibit osteoblast proliferation, decrease the number of foci of bone tissue mineralization and stimulate the formation of bone cavities by osteoclasts. ${ }^{13}$ These findings suggest that fenspiride may influence bone metabolism and BMD. The impact of different antagonists of H1-receptors (e.g., loratadine, cetirizine, pheniramine maleate) on bone metabolism has been studied, ${ }^{11,14,15}$ but to the best of our knowledge, the action of fenspiride on bone metabolism has not been investigated.

The aim of the study was to assess the influence of longterm administration of fenspiride on BMD and selected markers of bone turnover in young growing rats.

\section{Material and methods}

\section{Drugs and chemicals}

The drugs used in the study included Pulneo (fenspiride hydrochloricum) $25 \mathrm{mg} / 1 \mathrm{~mL}$ oral drops solution (Aflofarm
Farmacja Polska Sp. z o.o., Pabianice, Poland); normal saline solution (B. Braun Melsungen AG, Melsungen, Germany); ketamine $10 \%$ solution for injection for veterinary use, 100 mg/mL (Biowet Puławy Sp. z o.o., Puławy, Poland); and Relanium (diazepam) ampules, $5 \mathrm{mg} / \mathrm{mL}$ (Polfa S.A., Warszawa, Poland).

\section{The animals and the experiment}

The experiment was carried out on 18 8-week-old male Wistar rats with body weight of 190-270 g (mean weight $227.8 \pm 22.6 \mathrm{~g})$. The animals were housed at room temperature $\left(21-23^{\circ} \mathrm{C}\right)$ with $12: 12$-hour light-dark cycles. They were fed with a standard diet (LSM, Agropol sp. j., Motycz, Poland) that contained $1.2 \%$ calcium and $0.7 \%$ phosphates. Food and water were provided ad libitum.

Once acclimated, the rats were randomly assigned to 1 of 2 groups ( 9 animals in each group): group $F$ received fenspiride at a dose of $15 \mathrm{mg} / \mathrm{kg}$ (dosing based on a publication by Kuzubova et al. ${ }^{16}$ ), or group C (the control group) which received saline solution. The fenspiride and saline solution were given intragastrically (ig) once daily for 90 days (the time needed to cause significant changes in BMD).

Body weights were checked once daily throughout the experimental period. On day 1 and day 93, blood samples were collected from the tail vein for serum isolation. The serum was separated by centrifugation (at $1500 \times \mathrm{g}$ ) and then stored at $-70^{\circ} \mathrm{C}$ until required for bone metabolic marker assays. On days 2 and 92, dual-energy X-ray absorptiometry (DXA) was performed under general anesthesia with ketamine (50 mg/kg intraperitoneally (ip)) and diazepam (3 $\mathrm{mg} / \mathrm{kg}$ ip).

The animals were sacrificed in deep narcosis with ketamine (50 mg/kg ip) and diazepam (3 mg/kg ip) on day 93. Femurs and tibias were collected from each animal for further examination.

\section{Ethical approval}

All applicable international, national and/or institutional guidelines for the care and use of animals were followed. The experiment was performed with the approval of the Local Ethics Committee for Experiments on Animals at the Wroclaw Medical University, Poland (approval No. 25/2016). All the procedures involving animals performed during the study were in accordance with the ethical standards and practices of the institution where the study was conducted.

\section{Parameters of bone turnover}

Total calcium concentration and inorganic phosphorus measurements were performed by a certified laboratory with an Architect Plus ci4100 chemistry analyzer (Abbott Laboratories, Lake Bluff, USA) using commercial tests (Architect/Aeroset Calcium Assay and Architect 
Phosphorus Assay, both from Abbott Laboratories) according to the manufacturer's instructions. Levels of parathormone (PTH), osteocalcin, C-terminal telopeptide of type I collagen (bCTX), osteoprotegerin (OPG), and receptor activator of nuclear factor kappa B ligand (RANKL) were measured with the following commercial enzyme-linked immunosorbent assay (ELISA) kits: Rat Intact PTH ELISA Kit (Immutopics Inc., San Clemente, USA); Rat Osteocalcin ELISA Kit (SEA471Ra, USCN Life Science Inc., Houston, USA); Rat Beta-Crosslaps ELISA Kit (USCN Life Science Inc.); Rat Osteoprotegerin ELISA Kit (USCN Life Science Inc.); and Rat Receptor Activator of Nuclear Factor Kappa B Ligand ELISA Kit (USCN Life Science Inc.), respectively, according to manufacturers' instructions.

\section{Dual-energy X-ray absorptiometry}

Dual-energy X-ray absorptiometry (DXA) was performed on a high-resolution Discovery W (S/N) 81507 device (Hologic Inc., Marlborough, USA). Bone mineral density and fat content were measured.

\section{Macrometric measurements}

After sacrificing the animals, the right tibia and right femur were collected from each rat. The bones were weighed using electronic scales (Radwag, Radom, Poland). The bone lengths and mid-length diameter of the diaphysis were measured using digital calipers with a resolution of $0.01 \mathrm{~mm}$ (Pro sp.z o.o., Bielsko-Biała, Poland). For each bone, the femur index, defined as the ratio of femur weight and body weight ((femur mass [g]) / (body mass [g]) × 100), or tibial index ((tibia mass [g]) / (body mass [g]) $\times 100)$ were calculated.

\section{Statistical analysis}

The significance of differences between values was assessed using Student's t-test. P-values of less than 0.05 were considered statistically significant. The results were presented as means \pm standard deviation (SD).

The statistical analysis was performed using STATISTICA v. 10 software (StatSoft, Inc., Tulsa, USA).

\section{Results}

\section{Age and body weight}

On day 1, groups $\mathrm{F}$ and $\mathrm{C}$ were homogenous in terms of age (59.11 \pm 1.05 days vs $60 \pm 3.87$ days, $\mathrm{p}>0.05)$, body weight (274.4 $\pm 26.4 \mathrm{~g}$ vs $272.2 \pm 23.9 \mathrm{~g}, \mathrm{p}>0.05)$ and fat content $(15.0 \pm 2.0 \%$ of body weight vs $14.2 \pm 3.1 \%$ of body weight, $\mathrm{p}>0.05)$. No significant difference between the groups in the dynamic of body weight gain was observed throughout the experimental period, and therefore on day 93 body weight (413.3 $\pm 41.2 \mathrm{~g}$ in group $\mathrm{F}$ vs $424.4 \pm 35.0 \mathrm{~g}$ in group $\mathrm{C}, \mathrm{p}>0.05)$ and fat content were comparable in the 2 groups $(20.5 \pm 4.2 \%$ of body weight in group F vs $19.7 \pm 4.4 \%$ of body weight in the controls, $\mathrm{p}>0.05)$.

\section{Parameters of bone turnover}

The results are presented in Table 1. On days 1 and 93, no significant differences between groups $\mathrm{F}$ and $\mathrm{C}$ were found in any of the analyzed serum bone turnover markers (osteocalcin, bCTX), regulatory proteins (RANKL, OPG) or total calcium and inorganic phosphorus concentrations.

Table 1. The effect of fenspiride treatment on the serum concentration of selected markers of bone turnover

\begin{tabular}{|c|c|c|c|c|}
\hline & Parameter & $\begin{array}{l}\text { Fenspiride group } \\
\qquad(n=9)\end{array}$ & $\begin{array}{l}\text { Control group } \\
\qquad(n=9)\end{array}$ & $\mathrm{p}$-value \\
\hline \multirow{6}{*}{ Day 1} & osteocalcin [ng/mL] & $1.00 \pm 0.11$ & $0.95 \pm 0.18$ & NS \\
\hline & $\mathrm{bCTX}[\mathrm{ng} / \mathrm{mL}]$ & $0.28 \pm 0.05$ & $0.29 \pm 0.12$ & NS \\
\hline & RANKL [pg/mL] & $0.17 \pm 0.41$ & $1.02 \pm 1.27$ & NS \\
\hline & $\mathrm{OPG}[\mathrm{pg} / \mathrm{mL}]$ & $3.50 \pm 0.63$ & $3.80 \pm 0.69$ & NS \\
\hline & total calcium [mg/dL] & $9.14 \pm 0.76$ & $8.60 \pm 1.02$ & NS \\
\hline & inorganic phosphorus [mg/dL] & $6.63 \pm 0.42$ & $6.26 \pm 0.87$ & NS \\
\hline \multirow{7}{*}{ Day 93} & osteocalcin [ng/mL] & $0.42 \pm 0.09$ & $0.43 \pm 0.08$ & NS \\
\hline & $\mathrm{bCTX}[\mathrm{ng} / \mathrm{mL}]$ & $0.31 \pm 0.08$ & $0.29 \pm 0.08$ & NS \\
\hline & RANKL $[\mathrm{pg} / \mathrm{mL}]$ & $0.65 \pm 0.85$ & $0.56 \pm 0.86$ & NS \\
\hline & OPG [pg/mL] & $5.47 \pm 0.78$ & $5.35 \pm 1.65$ & NS \\
\hline & total calcium [mg/dL] & $6.38 \pm 1.50$ & $6.83 \pm 1.71$ & NS \\
\hline & inorganic phosphorus [mg/dL] & $5.19 \pm 1.76$ & $5.50 \pm 1.32$ & NS \\
\hline & PTH [pg/mL] & $237 \pm 182$ & $289 \pm 200$ & NS \\
\hline
\end{tabular}

bCTX - C-terminated telopeptide of type I collagen; RANKL - receptor activator of nuclear factor kappa B ligand; OPG - osteoprotegerin;

PTH - parathormone; NS - not significant; SD - standard deviation. Values are presented as means \pm SD. 
Table 2. The effect of fenspiride treatment on BMD and bone macrometric parameters

\begin{tabular}{|c|c|c|c|c|}
\hline & Parameter & $\begin{array}{l}\text { Fenspiride group } \\
\qquad(\mathrm{n}=9)\end{array}$ & $\begin{array}{l}\text { Control group } \\
\qquad(n=9)\end{array}$ & $p$-value \\
\hline \multirow{4}{*}{ Day 2} & total body BMD $\left[\mathrm{g} / \mathrm{cm}^{2}\right]$ & $0.160 \pm 0.007$ & $0.161 \pm 0.006$ & NS \\
\hline & lower limbs BMD [g/cm²] & $0.188 \pm 0.028$ & $0.1788 \pm 0.034$ & NS \\
\hline & femur BMD $\left[\mathrm{g} / \mathrm{cm}^{2}\right]$ & $0.232 \pm 0.006$ & $0.226 \pm 0.008$ & NS \\
\hline & tibia BMD $\left[\mathrm{g} / \mathrm{cm}^{2}\right]$ & $0.181 \pm 0.018$ & $0.175 \pm 0.016$ & NS \\
\hline \multirow{13}{*}{ Day 93} & total body BMD $\left[\mathrm{g} / \mathrm{cm}^{2}\right]$ & $0.212 \pm 0.010$ & $0.204 \pm 0.024$ & NS \\
\hline & lower limbs global BMD [g/cm²] & $0.264 \pm 0.016$ & $0.252 \pm 0.027$ & NS \\
\hline & femur BMD $\left[\mathrm{g} / \mathrm{cm}^{2}\right]$ & $0.292 \pm 0.016$ & $0.276 \pm 0.033$ & NS \\
\hline & tibia BMD $\left[\mathrm{g} / \mathrm{cm}^{2}\right]$ & $0.236 \pm 0.017$ & $0.228 \pm 0.024$ & NS \\
\hline & tibia mass [g] & $1.12 \pm 0.12$ & $1.04 \pm 0.10$ & NS \\
\hline & tibia index [\%] & $0.27 \pm 0.04$ & $0.25 \pm 0.02$ & NS \\
\hline & tibia length [mm] & $42.43 \pm 0.79$ & $42.27 \pm 1.05$ & NS \\
\hline & mid-length diameter of tibia [mm] & $3.77 \pm 0.16$ & $3.67 \pm 0.29$ & NS \\
\hline & femur mass $[\mathrm{g}]$ & $1.44 \pm 0.11$ & $1.38 \pm 0.12$ & NS \\
\hline & femur index [\%] & $0.35 \pm 0.04$ & $0.32 \pm 0.01$ & NS \\
\hline & femur length $[\mathrm{mm}]$ & $37.74 \pm 0.69$ & $38.01 \pm 0.62$ & NS \\
\hline & mid-length diameter of femur [mm] & $4.88 \pm 0.25$ & $4.76 \pm 0.28$ & NS \\
\hline & neck diameter of femur [mm] & $6.08 \pm 0.42$ & $6.12 \pm 0.25$ & NS \\
\hline
\end{tabular}

BMD - bone mineral density; NS - not significant; SD - standard deviation. Values are presented as means \pm SD.

Parathyroid hormone levels were measured only on day 93, and no significant difference between the 2 groups was detected.

\section{Bone mineral density and macrometric bone parameters}

Bone mineral density and macrometric bone parameters are presented in Table 2. No significant influence of fenspiride was detected on the parameters analyzed.

\section{Discussion}

Histamine exerts its action through membrane receptors $(\mathrm{H} 1, \mathrm{H} 2, \mathrm{H} 3$, and $\mathrm{H} 4)$ localized in most of the tissues and cells in the organism. ${ }^{17} \mathrm{H} 1$-antihistamines are widely used in the treatment of allergic disorders and acute or chronic urticarial. ${ }^{18}$ However, little is known about the action of $\mathrm{H1}$-antihistamines on bones during the developmental phase in immature organisms. ${ }^{19}$

Histamine is a biogenic amine widely distributed throughout the peripheral tissues of the body, and is found in neurons in the central nervous system. ${ }^{17}$ The influence of histamine on bone metabolism and the development of osteoporosis was suggested after some observational studies indicating that in patients with systemic mastocytosis, osteoporosis is relatively frequent. ${ }^{20}$ It is now well known that histamine is involved in the regulation of osteoclast differentiation through autocrine and paracrine signaling. Histamine increases the number of both osteoclasts and precursors of osteoclasts. What is more, preosteoclasts are also able to synthetize and release histamine. In primary osteoclasts, histamine increases the ratio of RANKL to osteoprotegerin (OPG) ${ }^{21}$ It has been documented that histamine increases the synthesis of osteoclast differentiation factor/RANKL in osteoblasts. ${ }^{22}$ The RANK/RANKL/OPG system plays an important and crucial role in bone metabolism regulation. ${ }^{23}$

Due to the common use of fenspiride in clinical practice, especially in pediatrics, and very often in long-term therapy, the aim of our study was to assess the impact of fenspiride on bone metabolism during intensive bone growth to answer the question of whether the use of the drug negatively influences bone growth and metabolism. We chose a wellestablished experimental model on young growing rats, often used in this type of experiments. ${ }^{24-26}$ We checked selected markers of bone metabolism, such as serum concentrations of osteocalcin, C-terminal telopeptide of type I collagen, RANKL, osteoprotegerin, serum total calcium, inorganic phosphorus, and PTH. Bone mineral density was assessed with densitometric measurements. Additionally, macrometric bone parameters of each animal's right tibia and right femur were measured, tibia and femur indices were calculated (expressed per body mass), and the diameters of the tibias and femurs were measured in typical localizations. All the results demonstrated that the 3-month-long administration of fenspiride to young male rats did not exert any negative impact on bone metabolism parameters.

Observational studies in humans indicate that patients with allergic disorders (e.g., allergies to pollens) who are 
not treated with any $\mathrm{H} 1$-antihistamine drugs suffer almost 3 times more frequently from low-energy bone fractures when compared to patients treated with such agents. Some authors have suggested that this might be due to higher histamine levels in untreated patients. ${ }^{27}$ It has been shown in experimental studies that H1-histamine receptor antagonists can inhibit histamine-induced osteoclastogenesis ${ }^{28}$ as well as age-related bone loss. ${ }^{29}$ The results of some experimental studies suggest that $\mathrm{H} 1$-antihistamine agents have no negative impact on bone metabolism and may even have a beneficial influence. ${ }^{30}$

In relatively early experimental research, the administration of promethazine (an H1-antihistamine agent) to female ovariectomized rats decreased bone resorption and increased BMD. ${ }^{29}$ Treatment with cetirizine (a $2^{\text {nd }}$ generation H1-antihistamine) did not have any impact on BMD values or bone tissue properties in $\mathrm{H}(+) / \mathrm{K}(+)$ ATPase $\beta$ subunit knockout (KO) mice, which are genetically modified to have high histamine levels leading to secondary decreases in BMD. ${ }^{11,31}$ Recently, Folwarczna et al. ${ }^{14}$ administered loratadine (a $2^{\text {nd }}$ generation $\mathrm{H} 1$-antihistamine) to ovariectomized and non-ovariectomized rats with bone metabolism disorders. Short-term loratadine administration significantly improved bone metabolism and biomechanical bone properties in the non-ovariectomized rats.

The function of osteoclasts and osteoblasts may be influenced not only by histamine alone, but also by chronic inflammatory processes, directly and indirectly. Bone metabolism strongly depends on the interaction of a variety of substances (growth factors, cytokines, hormones) with bone cells. The final effect of these interactions in cases of chronic inflammation leads to bone loss rather than bone formation. ${ }^{23}$ There is data suggesting close relationships between prostaglandins, leukotrienes and pro-inflammatory cytokines, and bone turnover. ${ }^{32}$ In vitro studies have shown increased differentiation of mesenchymal stem cells in the presence of pranlukast (a CysLT1 receptor antagonist). ${ }^{33}$ In experimental animal models of bone fractures, both zileuton (a 5-lipooxygenase inhibitor) and montelukast (a CysLT1 receptor antagonist) increased chondrocyte proliferation and led to quicker bone formation. ${ }^{34}$

Our results demonstrate that long-term therapy with fenspiride does not have a negative impact on the growing skeleton. Taking into account the negative impact on bone metabolism of increased histamine levels connected with chronic allergic reactions, it may be assumed that in children with allergic disorders, fenspiride may even have a protective effect.

\section{References}

1. Kanis JA. Osteoporosis III: Diagnosis of osteoporosis and assessment of fracture risk. Lancet. 2002;359(9321):1929-1936. doi:10.1016/S01406736(02)08761-5

2. Hernlund E, Svedbom A, Ivergård M, et al. Osteoporosis in the European Union: Medical management, epidemiology and economic burden. Arch Osteoporos. 2013;8(1-2):136. doi:10.1007/s11657-013-0136-1
3. Ferrari S, Bianchi ML, Eisman JA, et al. Osteoporosis in young adults: Pathophysiology, diagnosis, and management. Osteoporos Int. 2012; 23(12):2735-2748. doi:10.1007/s00198-012-2030-x

4. Rizzoli R, Bianchi ML, Garabédian M, McKay HA, Moreno LA. Maximizing bone mineral mass gain during growth for the prevention of fractures in the adolescents and the elderly. Bone. 2010;46(2):294305. doi:10.1016/j.bone.2009.10.005

5. Heaney RP, Abrams S, Dawson-Hughes B, et al. Peak bone mass. Osteoporos Int. 2000;11(11):985-1009. doi:10.1007/s001980070020

6. Viswanathan A, Sylvester FA. Chronic pediatric inflammatory diseases: Effects on bone. Rev Endocr Metab Disord. 2008;9(2):107-122. doi:10.1007/s11154-007-9070-0

7. Zhang Y, Zheng YX, Zhu JM, Zhang JM, Zheng Z. Effects of antiepileptic drugs on bone mineral density and bone metabolism in children: A meta-analysis. J Zhejiang Univ Sci B. 2015;16(7):611-621. doi:10.1631/ jzus.B1500021

8. Shmelev El, Kunicina YL. Comparison of fenspiride with beclomethasone as adjunctive anti-inflammatory treatment in patients with chronic obstructive pulmonary disease. Clin Drug Investig. 2006;26(3): $151-159$.

9. Volkova LI, Budkova AA, Filonova NN, et al. Efficacy of a complementary anti-inflammatory treatment with erespal in chronic obstructive and nonobstructive bronchitis. Ter Arkh. 2004.

10. Khawaja AM, Liu YC, Rogers DF. Effect of fenspiride, a non-steroidal anti-inflammatory agent, on neurogenic mucus secretion in ferret trachea in vitro. Pulm Pharmacol Ther. 1999;12(6):363-368. doi:10. 1006/pupt.1999.0221

11. Aasarod KM, Stunes AK, Mosti MP, et al. Effects of the histamine 1 receptor antagonist cetirizine on the osteoporotic phenotype in $\mathrm{H}+/ \mathrm{K}+$ ATPase beta subunit KO mice. J Cell Biochem. 2016;117(9):2089-2096. doi:10.1002/jcb.25514

12. Blackwell KA, Raisz LG, Pilbeam CC. Prostaglandins in bone: Bad cop, good cop? Trends Endocrinol Metab. 2010;21(5):294-301. doi:10.1016/j. tem.2009.12.004

13. Hikiji H, Takato T, Shimizu T, Ishii S. The roles of prostanoids, leukotrienes, and platelet-activating factor in bone metabolism and disease. Prog Lipid Res. 2008;47(2):107-126. doi:10.1016/j.plipres.2007.12.003

14. Folwarczna J, Janas A, Pytlik M, Śliwiński L, Wiercigroch M, Brzęczek A. Modifications of histamine receptor signaling affect bone mechanical properties in rats. Pharmacol Reports. 2014;66(1):93-99. doi:10. 1016/j.pharep.2013.08.010

15. Ezzat $\mathrm{BA}, \mathrm{Abb}$ ass MMS. The ability of $\mathrm{H} 1$ or $\mathrm{H} 2$ receptor antagonists or their combination in counteracting the glucocorticoid-induced alveolar bone loss in rats. J Oral Pathol Med. 2014;43(2):148-156. doi: 10.1111/jop.12104

16. Kuzubova NA, Lebedeva ES, Fedin AN, Dvorakovskaya IV, Preobrazhenskaya TN, Titova ON. Effect of fenspiride on bronchial smooth muscle of rats with chronic obstructive pulmonary disease. J Smooth Muscle Res. 2013;49:46-54. doi:10.1540/jsmr.49.46

17. Cataldi M, Borriello F, Granata F, Annunziato L, Marone G. Histamine receptors and antihistamines: From discovery to clinical applications. Chem Immunol Allergy. 2014;100:214-226. doi:10.1159/000358740

18. Fitzsimons R, van derPoel L-A, ThornhillW, du ToitG, Shah N, Brough HA. Antihistamine use in children. Arch Dis Child Educ Pract Ed. 2015; 100(3):122-131. doi:10.1136/archdischild-2013-304446

19. De Benedictis FM, De Benedictis D, Canonica GW. New oral H1 antihistamines in children: Facts and unmet needs. Allergy Eur J Allergy Clin Immunol. 2008;63(10):1395-1404. doi:10.1111/j.1398-9995.2008. 01771.x

20. Barete S, Assous N, de Gennes C, et al. Systemic mastocytosis and bone involvement in a cohort of 75 patients. Ann Rheum Dis. 2010; 69(10):1838-1841. doi:10.1136/ard.2009.124511

21. Biosse-Duplan M, Baroukh B, Dy M, de Vernejoul M-C, Saffar J-L. Histamine promotes osteoclastogenesis through the differential expression of histamine receptors on osteoclasts and osteoblasts. Am J Pathol. 2009;174(4):1426-1434. doi:10.2353/ajpath.2009. 080871

22. Deyama Y, Kikuiri T, Ohnishi Gl, et al. Histamine stimulates production of osteoclast differentiation factor/receptor activator of nuclear factor-kappaB ligand by osteoblasts. Biochem Biophys Res Commun. 2002;298(2):240-246. doi:10.1016/S0006-291X(02)02440-3 
23. Neumann $\mathrm{E}$, Müller-Ladner U, Frommer KW. Entzündung und Knochenmetabolismus. Z Rheumatol. 2014;73(4):342-348. doi:10.1007/ s00393-013-1288-5

24. Lelovas PP, Xanthos TT, Thorma SE, Lyritis GP, Dontas IA. The laboratory rat as an animal model for osteoporosis research. Comp Med. 2008;58(5):424-430.

25. Tauer JT, Hofbauer LC, Jung R, et al. Impact of long-term exposure to the tyrosine kinase inhibitor imatinib on the skeleton of growing rats. PLoS One. 2015;10(6):e0131192. doi:10.1371/journal.pone.0131192

26. Lin S, Huang J, Zheng L, et al. Glucocorticoid-induced osteoporosis in growing rats. Calcif Tissue Int. 2014;95(4):362-373. doi:10.1007/ s00223-014-9899-7

27. Ferencz V, Meszaros S, Csupor E, et al. Increased bone fracture prevalence in postmenopausal women suffering from pollen-allergy. Osteoporos Int. 2006;17(3):484-491. doi:10.1007/s00198-005-0011-z

28. Ikawa Y, Yonekawa T, Ohkuni Y, Kuribayashi M, Fukino K, Ueno K. A comparative study of histamine activities on differentiation of osteoblasts and osteoclasts. J Toxicol Sci. 2007;32(5):555-564. doi:10.2131/jts.32.555
29. Rico H, Gómez M, Revilla M, et al. Effects of promethazine on bone mass and on bone remodeling in ovariectomized rats: A morphometric, densitometric, and histomorphometric experimental study. Calcif Tissue Int. 1999;65(4):272-275. doi:10.1007/s002239900697

30. Kinjo M, Setoguchi S, Solomon DH. Antihistamine therapy and bone mineral density: Analysis in a population-based US sample. Am JMed. 2008;121(12):1085-1091. doi:10.1016/j.amjmed.2008.06.036

31. Meh A, Sprogar Š, Vaupotic T, et al. Effect of cetirizine, a histamine $(\mathrm{H} 1)$ receptor antagonist, on bone modeling during orthodontic tooth movement in rats. Am J Orthod Dentofac Orthop. 2011;139(4): e323-329. doi:10.1016/j.ajodo.2009.11.013

32. Gatti D, Senna G, Viapiana O, Rossini M, Passalacqua G, Adami S. Allergy and the bone: Unexpected relationships. Ann Allergy Asthma Immunol. 2011;107(3):202-206. doi:10.1016/j.anai.2011.03.018

33. Akino K, Mineda T, Mori N, Hirano A, Imaizumi T, Akita S. Attenuation of cysteinyl leukotrienes induces human mesenchymal stem cell differentiation. Wound Repair Regen. 2006;14(3):343-349. doi:10.1111/ j.1743-6109.2006.00130.x

34. Wixted JJ, Fanning PJ, Gaur T, et al. Enhanced fracture repair by leukotriene antagonism is characterized by increased chondrocyte proliferation and early bone formation: A novel role of the cysteinyl IL-1 receptor. J Cell Physiol. 2009;221(1):31-39. doi:10.1002/jcp.21809 